\title{
RANCANG BANGUN APLIKASI KURSUS ONLINE BERBASIS WEB DENGAN SISTEM REKOMENDASI METODE CONTENT-BASED FILTERING
}

\author{
${ }^{1)}$ Yefta Christian, ${ }^{2)}$ Kelvin \\ ${ }^{1,2)}$ Sistem Informasi, Fakultas Teknik, Universitas Internasional Batam \\ 1,2) Jl. Gajah Mada Batam - Kepulauan Riau - Indonesia \\ E-mail: ${ }^{1)}$ yefta @uib.ac.id, ${ }^{2)}$ 1831148.kelvin@uib.edu
}

\begin{abstract}
ABSTRAK
Lembaga Kursus dan Pelatihan (LKP) merupakan pendidikan non-formal yang menyediakan berbagai pelatihan khusus untuk mendidik keterampilan pelajar. Namun, terdapat hal yang sering menjadi kendala bagi calon pelajar yaitu bingung melakukan dalam melakukan pemilihan kursus sesuai dengan preferensinya. Oleh karena itu, tujuan dari penelitian ini adalah merancang sebuah aplikasi kursus online dengan sistem rekomendasi metode Contentbased Filtering. Selain itu, penelitian ini juga menerapkan algoritma cosine similarity untuk menentukan kursus yang serupa dengan riwayat kursus yang pernah diakses oleh pengguna. Dataset yang digunakan untuk menjalankan algoritma sistem rekomendasi diambil dari situs Kaggle berjudul "Udemy Course" dengan jumlah data sebanyak 3,682 records. Hasil akhir dari penelitian ini adalah sebuah aplikasi kursus online yang dapat memberikan rekomendasi kursus berdasarkan nilai kesamaan yang paling tinggi dari algoritma cosine similarity.

Kata Kunci: Pemelajaran tak terarah, Content-based Filtering, Sistem Rekomendasi, Pembelajaran Mesin
\end{abstract}

\begin{abstract}
The Institute for Courses and Training is a non-formal education that provides various special training to educate students' skills. However, there are things that often become obstacles for prospective students, namely being confused about choosing courses according to their preferences. Therefore, the purpose of this research is to design an online course application with a recommendation system for the Content-based Filtering method. In addition, this research also applies the cosine similarity algorithm to determine courses that are similar to the course history that has been accessed by the user. The dataset used to run the recommendation system algorithm was taken from the Kaggle website entitled "Udemy Course" with a total of 3,682 records. The final result of this research is an online course application that can provide course recommendations based on the highest similarity value from the cosine similarity algorithm.
\end{abstract}

Keyword: Unsupervised Learning, Content-based Filtering, System Recommender, Machine Learning

\section{PENDAHULUAN}

Penerapan teknologi informasi ini semakin menonjol pada saat kondisi pandemi Covid-19 (Coronavirus Disease 2019). Khususnya dalam dunia pendidikan, karena setiap lembaga pendidikan termasuk sekolah diwajibkan untuk melakukan pembelajaran secara daring (online) [1]. Selain itu, penerapan teknologi informasi juga dapat membantu sekolah dalam meningkatkan keterampilan siswa, terutama pada tingkat Sekolah Menengah Kejuruan (SMK). SMK merupakan lembaga pendidikan nasional yang memiliki tugas pokok dalam mendidik dan mengembangkan keterampilan siswa agar dapat menjadi pekerja tingkat menengah di dalam suatu bidang usaha [2].

Selain itu, terdapat juga sarana lainnya yang dapat membantu siswa dalam mengembangkan keterampilan, yaitu dengan mengikuti Lembaga Kursus dan Pelatihan (LKP). Kursus disebut sebagai pendidikan non-formal yang bisa didapatkan di luar kegiatan sekolah [3]. Lembaga Kursus dan Pelatihan (LKP) menyediakan berbagai pelatihan khusus yang langsung berhubungan dengan dunia kerja, seperti pelatihan 
pemrograman, akuntansi dan sebagainya. Dengan mengikuti kursus, siswa bisa mendapat berbagai pelatihan pengembangan diri dalam waktu singkat [4].

Batam merupakan kota terbesar di Provinsi Kepulauan Riau, terletak pada jalur pelayaran internasional yang berbatasan langsung dengan negara Singapura dan Malaysia [5]. Menurut informasi pengangguran dari Badan Pusat Statistik (BPS), tercatat jumlah pengangguran di Kota Batam pada tahun 2020 sebanyak 87,903 orang [6]. Diukur dari latar belakang pendidikan, tingkat pengangguran terbuka (TBT) tertinggi di Kota Batam jatuh pada tamatan Sekolah Menengah Kejuruan (SMK) adalah sebesar 14,09\% [6]. Begitu juga jumlah pengangguran di seluruh Indonesia pada bulan Agustus 2020 mencapai 9,7 juta orang, dengan tingkat pengangguran terbuka (TBT) tertinggi jatuh pada tamatan Sekolah Menengah Kejuruan (SMK) sebesar 13,55\% [7].

Dari hal tersebut dapat disimpulkan bahwa faktor utama penyebab pengangguran adalah kurangnya keterampilan pekerja tamatan SMK untuk memenuhi spesifikasi lapangan kerja yang ada dan persaingan dalam perebutan peluang kerja yang ketat dalam kondisi pandemi Covid-19 [8]. Oleh sebab itu, Lembaga Kursus Pendidikan (LPK) memiliki kontribusi yang besar untuk mengatasi masalah tersebut [9]. Namun, terdapat hal yang sering menjadi kendala bagi calon pelajar yaitu bingung melakukan dalam melakukan pemilihan kursus sesuai dengan minatnya [10]. Oleh karena itu diperlukan sebuah sistem rekomendasi kursus untuk membantu pelajar dalam melakukan pemilihan kursus.

Berdasarkan penelitian yang dilakukan oleh [10] menggunakan metode contentbased filtering untuk meracang sistem rekomendasi matakuliah. Dalam penelitian ini mengungkapkan bahwa hasil rekomendasi matakuliah dari metode content-based filtering sesuai dengan preferensi mahasiswa karena metode tersebut merekomendasikan matakuliah berdasarkan riwayat matakuliah yang pernah diambil pengguna.

Penelitian selanjutnya ditulis oleh [11] adalah penelitian tentang perancangan unsupervised machine learning untuk menentukan kesamaan tweet yang berkaitan dengan empat festival di Eropa. Penelitian ini menggunakan algoritma Cosine Similarity sebagai pendekatan unsupervised learning. Hasil dari penelitian ini menyatakan bahwa algoritma cosine similarity mampu menghasilkan nilai kesaman tinggi dalam mendeteksi kesamaan tweet dari Twitter dengan topik festival Eropa.

Penelitian selanjutnya ditulis oleh [12] adalah penelitian tentang perancangan sistem rekomendasi movie. Penelitian ini menggunakan algoritma Cosine Similarity dalam metode content based filtering. Dalam penelitian ini menjelaskan bahwah sebelum memproses algoritma cosine similarity, diperlukan untuk melakukan penghapusan stopwords.

Penelitian selanjutnya ditulis oleh [13] adalah penelitian terapan yang dilakukan pada LKP Istikom. Dalam penelitian ini menjelaskan bahwa perancangan aplikasi kursus online sangat dibutuhkan pada masa COVID-19, karena dapat membantu melakukan pembelajaran dimana saja dan kapan saja. Penelitian ini menggunakan metode SDLC (System Development Life Cycle), bahasa pemrograman PHP dan database Mysql dan melakukan proses pengembangan aplikasi. Hasil dari penelitian ini adalah sebuah aplikasi kursus online yang dapat membantu LKP Istikom dalam 
melakukan pengajaran secara online.

Penelitian selanjutnya ditulis oleh [14] adalah penelitian terapan tentang perancangan aplikasi pendidikan berbasis web pada startup Sinau Yo. Tujuan dari penelitian ini adalah merancang sebuah aplikasi pendidikan online yang dapat menawarkan fitur penawaran guru kepada siswa dan pelaksanaan pembelajaran secara online. Penelitian ini menggunakan metode iterative incremental, framework laravel dan database Mysql untuk melakukan proses pengembangan aplikasi. Hasil penelitian ini adalah sebuah aplikasi web pendidikan yang membantu bisnis proses utama pada startup Sinau Yo dalam memberikan pembelajaran kepada murid secara daring .

Penelitian selanjutnya ditulis oleh [15] adalah penelitian terapan yang berfokus pada pengembangan aplikasi reservasi massage berbasis web dengan metode scrum. Kesimpulan dari penelitian ini menjelaskan bahwa proses pengembangan sistem dengan metode scrum dapat lebih fleksibel menghadapi perubahan yang akan terjadi dikarenakan proses pengembangan aplikasi dilacak dengan grafik yang dikenal dengan burndown chart.

Dari studi literatur yang telah disebutkan, tinjauan dari studi literatur tersebut disimpulkan ke dalam tabel 1 .

Tabel 1. Tinjauan studi literatur

\begin{tabular}{|c|c|c|}
\hline $\begin{array}{l}\text { Nama } \\
\text { Peneliti }\end{array}$ & Tahun & Kesimpulan \\
\hline $\begin{array}{l}\text { Morsomme } \\
\text { dan Alferez }\end{array}$ & 2019 & $\begin{array}{lr}\text { Penelitian } & \text { ini } \\
\text { mengungkapkan } & \text { bahwa } \\
\text { metode content-based } & \\
\text { filtering } & \text { mampu } \\
\text { memberikan } & \\
\text { rekomendasi } & \text { kursus } \\
\text { sesuai } & \text { preferensi } \\
\text { mahasiswa. } & \\
\end{array}$ \\
\hline $\begin{array}{l}\text { Focil-Arias } \\
\text { et al. }\end{array}$ & 2017 & $\begin{array}{l}\text { Penelitian } \\
\text { menjelaskan } \\
\text { algoritma } \\
\text { similarity }\end{array}$ \\
\hline
\end{tabular}

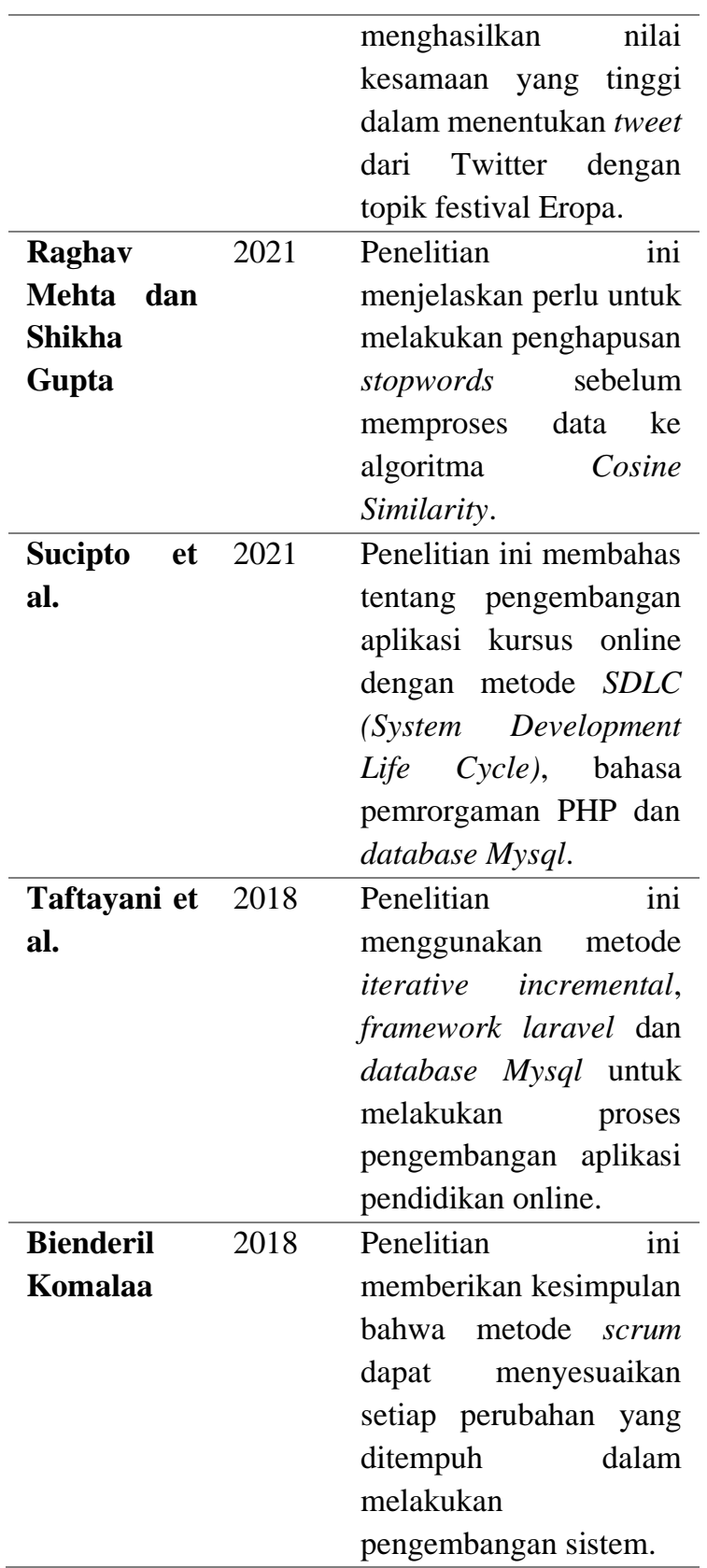

Berdasarkan uraian tersebut, dengan tujuan untuk mempermudah pelajar dalam mencari kursus sesuai preferensi masingmasing, maka penulis akan merancang sebuah aplikasi kursus online berbasis web dengan menerapkan sistem rekomendasi. Rancangan dan analisis aplikasi yang dikembangkan dengan metode scurm dan pendekatan content-based filtering pada sistem rekomendasinya, diharapkan dapat membantu pelajar dalam mencari kursus online untuk melakukan pengembangan keterampilan. 


\section{METODE}

\section{A. Metode Pengembangan Sistem}

Metode pengembangan aplikasi kursus online pada penelitian ini menggunakan metode scrum. Scrum merupakan metode pengembangan project yang menerapkan pendekatan agile dan berfokus pada memberikan nilai tertinggi dalam waktu singkat [16]. Metode ini berorientasi dengan tim yang menentukan peran tertentu, penetapan iterasi kotak waktu yang disebut sprint di mana sistem dikembangkan secara bertahap dan menghasilkan artefak berbeda yang mengoordinasikan pekerjaannya [17].

\section{SCRUM FRAMEWORK}

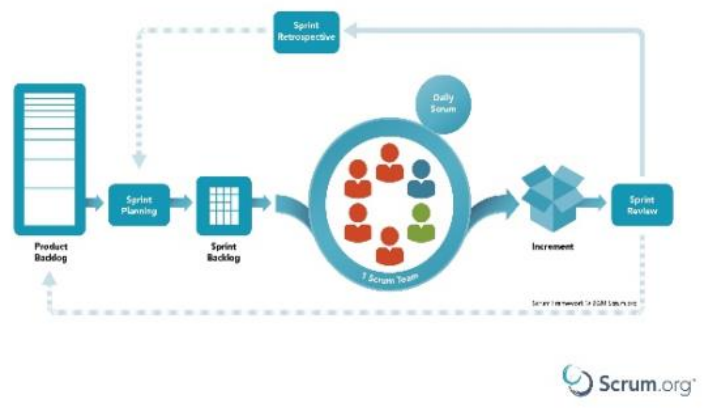

Gambar 1. Metode Perancangan

Sumber: [18]

Implementasi metode scrum terdiri atas beberapa langkah yaitu:

\section{a. Product Backlog}

Merupakan daftar persyaratan yang terkumpul dan harus dipenuhi pada produk akhir, mencakup amandemen yang mungkin diperlukan. Masing-masing poin di product backlog memiliki deskripsi, urutan, perkiraan, dan nilai tersendiri [19], pada point ini penulis akan berperan sebagai product owner untuk melakukan penyusunan product backlog. Fitur-fitur utama yang akan dirancang dalam sistem rekomendasi kursus online adalah sebagai berikut:

1. Sistem memiliki tiga user role, terdiri dari admin, mentor dan student
2. Admin memiliki seluruh akses $C R U D$ (Create, Read, Update, Delete) pada fitur yang ada pada sistem

3. Mentor dapat melakukan publikasi, mengedit dan menghapus sebuah paket kursus online pada sistem

4. Student dapat mendaftar kursus online yang dipublikasi oleh mentor

5. Fitur rekomendasi kursus kepada user dengan pendekatan content-based recommender dan algoritma cosine similarity.

\section{b. Sprint Planning}

Merupakan tahapan dimana ditentukan poin-poin pada product backlog yang akan dikerjakan dalam jangka waktu tertentu [20].

\section{c. Sprint Backlog}

Merupakan daftar pekerjaan yang sudah ditentuin dari sprint planning yang harus diselesaikan dalam satu sprint, selain itu sprint backlog juga dapat dimanfaatkan sebagai alat untuk memantau proses pengembangan proyek [19].

\section{d. Daily Scrum}

Merupakan tahapan yang perlu dilakukan setiap hari untuk melaporkan apa saja yang telah dilakukan pada hari sebelumnya [19].

\section{e. Sprint Review}

Setiap masa satu sprint selesai, akan melakukan sprint review kepada dosen pembimbing terhadap proyek yang sedang dikembangkan, dengan tujuan untuk mengevaluasi mengenai pekerjaan yang telah dicapai dan tersisa selama satu sprint. Selain itu, pada sprint review juga akan dilakukan pengujian proyek dengan metode blackbox, pengujian blackbox 
berupa pengujian alur fungsi-fungsi aplikasi serta keseuaian bisnis proses pada proyek yang dirancang. Kemudian akan melakukan revisi pada product backlog dan menentukan poin yang perlu dikerjakan dalam sprint selanjutnya [19].

\section{f. Sprint Retrospective}

Sprint Retrospective dilakukan setelah sprint review, dan sebelum sprint planning dimulai. Sprint Retrospective menawarkan kesempatan kepada dosen pembimbing untuk memeriksa apa yang telah diraih oleh penulis selama 1 sprint. Tujuan Sprint Retrospective untuk mendapatkan pendapat dan saran dari dosen pembimbing untuk mengembangkan rencana prosedur kerja dalam sprint berikutnya [19].

\section{g. Increment}

Merupakan hasil pengerjaan dari semua product backlog yang telah diselesaikan. Increment dikatakan "Selesai" artinya produk harus dalam kondisi yang bisa digunakan dan memenuhi definisi yang telah ditentukan yang mendukung empirisme di akhir Sprint. Increment merupakan langkah untuk mencapai tujuan akhir. Tahapan ini juga merupakan tahapan dimana product owner memutuskan untuk merilisnya [21].

\section{B. Struktur Pengembangan Sistem}

Struktur pengembangan sistem pada penelitian ini akan digambarkan dalam bentuk Use Case Diagram dan Entity Relationship Diagram (ERD). UCD berfungsi untuk menggambarkan pola kelakuan aktor terhadap sistem yang akan dirancang [22]. ERD berfungsi untuk menggambarkan model relasi antar table sebagai objek penyimpanan data [23].

\section{Model Pengembangan Sistem Rekomendasi}

Tahapan pengembangan sistem rekomendasi content-based filtering pada penelitian ini dimulai dari:

\section{Data Preparation}

Pada tahap ini penulis akan menggunakan dataset kursus udemy dari situs Kaggle yang terdiri dari attribute course_id, course_title, url, is_paid, price, num_subscribers, num_reviews, num_lectures, level, content_duration, subject, profit, published_date, published_time, year, month, day, published_timestamp dengan jumlah data 3.682 baris. Terdapat beberapa tahap dalam data preparation, yaitu:

a. Stopwords removal

Penulis akan melakukan penghapusan stopwords pada atribut course title yang akan dipakai untuk perbandingan kesamaan riwayat kursus pengguna [24]. Hal tersebut dilakukan untuk menghapus kata-kata yang tidak penting sebelum diproses oleh algoritma learning.

b. Count Vectorization

Count Vectorization (CV) merupakan teknik yang digunakan untuk melakukan perhitungan jumlah kata yang sering muncul dalam sebuah dokumen. Output dari CV ini adalah sebuah sparse matrix yang akan digunakan untuk kalkulasi algoritma cosine similarity [25].

\section{Content-based filtering}

Content-Based Filtering (CF) adalah metode rekomendasi suatu produk kepada pengguna berdasarkan deskripsi pada produk dan preferensi pengguna. Metode ini akan menawarkan item yang mirip dengan item yang pernah digunakan 
pengguna berdasarkan history penggunaannya. Tindakan perolehan data dapat berupa tindakan implisit atau eksplisit [26].

\section{Algorithm Cosine Similarity}

Cosine Similarity adalah algoritma yang digunakan untuk mengukur tingkat kemiripan dokumen berdasarkan ukurannya. Secara sistematis, cosine similarity ini mengukur kosinus sudut antara perkalian dua vektor yang diproyeksikan dalam ruang multidimensi. Semakin kecil sudutnya, semakin tinggi kesamaan cosinus [27]. Berikut rumus cosine similarity.

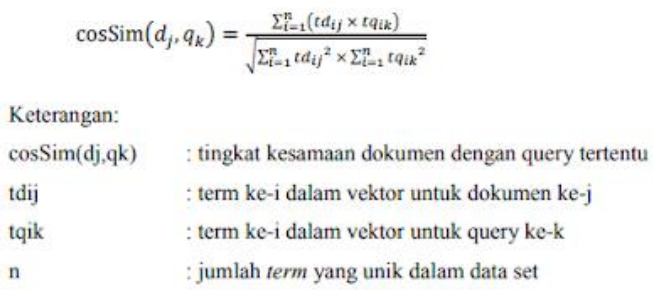

Pada penelitian akan menerapkan algoritma cosine similarity untuk menentukan rekomendasi kesamaan item pengguna dengan metode content-based filtering. Keuntungan penggunaan algoritma tersebut adalah memiliki nilai akurasi yang tinggi dalam menetukan kesamaan item seperti yang diungkapkan pada penelitian [12].

\section{Model Integrasi Aplikasi Kursus Online dan Sistem Rekomendasi}

Hasil perancangan aplikasi kursus online pada penelitian ini dinamai Perfect Course, dan diintegrasikan dengan sistem rekomendasi unsupervised learning. Teknik integrasi yang diterapkan untuk kedua aplikasi yang telah dirancang adalah microservices.

Microservices merupakan teknik integrasi API cloud modern, yang dibangun dari sekumpulan service yang berbeda dan masing-masing service tersebut saling memiliki interaksi melalui API [28].

Penerapan microservice pada penelitian ini menggunakan framework express js sebagai API Gateway dari aplikasi kursus online yang dibangun dengan REST-API framework laravel dan aplikasi sistem rekomendasi yang dibangun dengan microframework flask.

\section{HASIL}

\section{A. Hasil Penerapan Metode Scrum}

1. Scrum Team

Berikut adalah struktur scrum team yang telah disusun untuk melakukan pengembangan proyek.

Tabel 2. Scrum Team

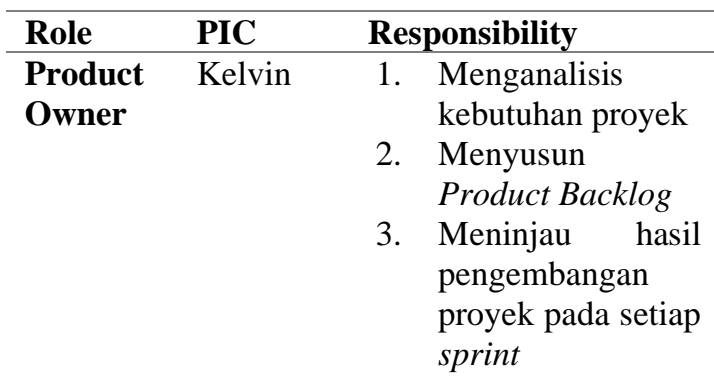

\begin{tabular}{|c|c|c|c|}
\hline $\begin{array}{l}\text { Scrum } \\
\text { Master }\end{array}$ & $\begin{array}{l}\text { Yefta } \\
\text { Christian }\end{array}$ & & $\begin{array}{l}\text { Memantau dan } \\
\text { memberikan } \\
\text { pengarahan } \\
\text { penerapan scrum } \\
\text { pada tim } \\
\text { Memantau } \\
\text { kemajuan product } \\
\text { backlog }\end{array}$ \\
\hline
\end{tabular}

\begin{tabular}{|c|c|c|c|}
\hline $\begin{array}{l}\text { Develop } \\
\text { ment } \\
\text { Team }\end{array}$ & Kelvin & & $\begin{array}{l}\text { Melakukan proses } \\
\text { pengembangan } \\
\text { proyek } \\
\text { Menguji hasil } \\
\text { pengembangan } \\
\text { proyek }\end{array}$ \\
\hline
\end{tabular}

\section{Product Backlog}

Hasil penyusunan product backlog terdiri atas 7 issue dan 24 sub-taks dari keseluruhan fitur yang perlu dikembangkan. Berikut adalah detail user story yang telah disusun: 
Tabel 3. Product Backlog

\begin{tabular}{|c|c|}
\hline Issue & User Story \\
\hline $\begin{array}{l}\text { Design Use } \\
\text { Diagram } \quad \& \\
\text { Entity } \\
\text { Relationship } \\
\text { Diagram }\end{array}$ & $\begin{array}{l}\text { As owner, I want to have } \\
\text { a UCD \& ERD as basic } \\
\text { structure of system } \\
\text { development } \\
\text { 1. Design Use Case } \\
\text { Diagram } \\
\text { 2. Design Entity } \\
\text { Relation Ship } \\
\text { Diagram }\end{array}$ \\
\hline $\begin{array}{l}\text { User } \\
\text { Authentication }\end{array}$ & $\begin{array}{l}\text { As owner, I want to have } \\
\text { basic authentication at } \\
\text { the system: } \\
\text { 1. Login } \\
\text { 2. Register } \\
\text { 3. Logout } \\
\text { 4. See user profile } \\
\text { 5. Edit Profile } \\
\text { 6. Change Password }\end{array}$ \\
\hline $\begin{array}{l}\text { User } \\
\text { Management }\end{array}$ & $\begin{array}{l}\text { As admin, i want to have } \\
\text { user management at the } \\
\text { system, so i can: } \\
\text { 1. See all list user } \\
\text { 2. Registeruser at the } \\
\text { system } \\
\text { 3. Edit user account }\end{array}$ \\
\hline $\begin{array}{l}\text { Course } \\
\text { Management }\end{array}$ & $\begin{array}{l}\text { As user, i want to manage } \\
\text { the course data at the } \\
\text { system: } \\
\text { 1. Publish and } \\
\text { unpublish course } \\
\text { 2. Edit Course } \\
\text { 3. Delete Course }\end{array}$ \\
\hline $\begin{array}{l}\text { Course } \\
\text { Enrollment \& } \\
\text { Payment Method }\end{array}$ & $\begin{array}{l}\text { As user, i want to } \\
\text { purchase the course at the } \\
\text { system. After i purchase } \\
\text { the course, i can: } \\
\text { 1. See all enrolled } \\
\text { course } \\
\text { 2. View the course } \\
\text { video }\end{array}$ \\
\hline $\begin{array}{l}\text { System } \\
\text { Recommendation } \\
\text { Course }\end{array}$ & $\begin{array}{l}\text { As a user, I would like to } \\
\text { have a recommendation } \\
\text { system that can offer } \\
\text { courses based on the } \\
\text { courses I have purchased }\end{array}$ \\
\hline $\begin{array}{l}\text { Microservice } \\
\text { Service Course } \\
\text { with } \quad \text { Service } \\
\text { Recommendation }\end{array}$ & $\begin{array}{l}\text { As developer, I want to } \\
\text { make API Gateway for } \\
\text { integrating all service } \\
\text { from course application } \\
\text { and service recommender } \\
\text { course with the } \\
\text { microservices method }\end{array}$ \\
\hline
\end{tabular}

\section{Sprint Planning}

Pada poin ini penulis menetapkan 1 sprint selama 2 minggu, dan perancangan proyek akan berlangsung selama 5 sprint. Berikut rangkuman sprint backlog yang telah dikerjakan selama 5 sprint.

Tabel 4. Sprint Planning

\begin{tabular}{|c|c|}
\hline Sprint & Sprint Backlog \\
\hline Sprint 1 & $\begin{array}{l}\text { 1. Perancangan Use Case } \\
\text { Diagram \& Entity } \\
\text { Relationship Diagram }\end{array}$ \\
\hline Sprint 2 & $\begin{array}{l}\text { 1. Perancangan Authentication } \\
\text { 2. Perancangan } \\
\text { management admin }\end{array}$ \\
\hline Sprint 3 & $\begin{array}{l}\text { 1. Perancangan } \\
\text { management }\end{array}$ \\
\hline Sprint 4 & $\begin{array}{l}\text { 1. Integrasi payment gateway } \\
\text { midtrans }\end{array}$ \\
\hline Sp & 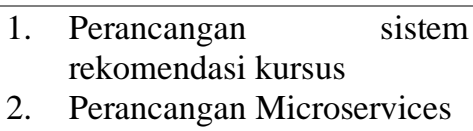 \\
\hline
\end{tabular}

4. Sprint Pertama

Dari sprint planning pertama, penulis berencana menyelesaikan product backlog desain Use Case Diagram (UCD) dan Entity Relationship Diagram (ERD). Berikut hasil review dari sprint pertama:

a. Use Case Diagram (UCD)

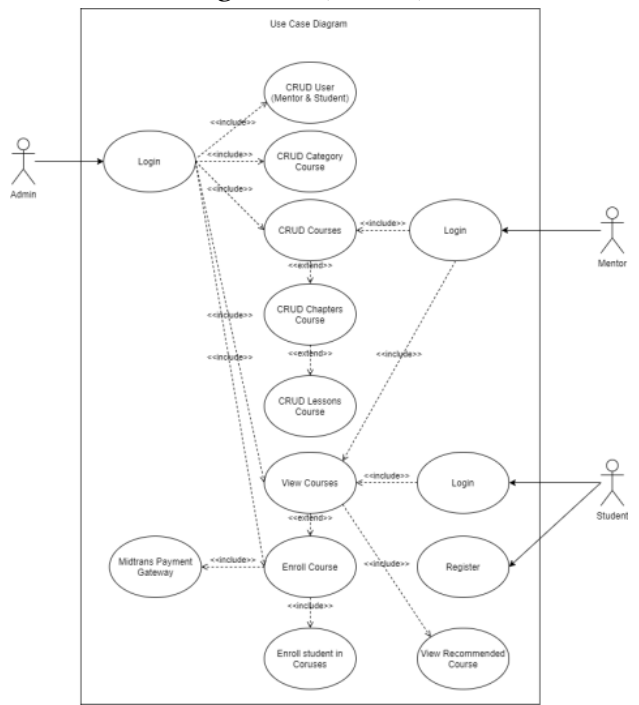

Gambar 2. Use Case Diagram (UCD)

Dari gambar 2 dapat mengetahui bahwa admin memiliki seluruh akses sistem dalam melakukan CRUD User, Category Courses, Courses, Chapters Course, Lessons Course, View 
Courses, dan Enroll Course. Untuk mentor memiliki akses sistem dalam melakukan CRUD Courses, Chapters Course dan Lessons Course. Untuk student memiliki akses dalam View Courses, dan Enroll Course.

b. Entity relationship diagram (ERD)

Pada gambar 3 menunjukan model yang digunakan untuk merancang database pada sistem rekomendasi kursus online.

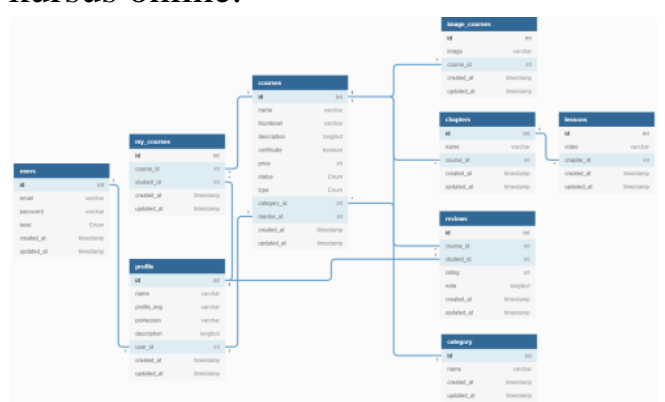

Gambar 3. Entity Relationship Diagram (ERD)

Adapun hasil sprint retrospective dari sprint pertama:

Tabel 5. sprint retrospective 1

\begin{tabular}{lll}
\hline $\begin{array}{l}\text { What went } \\
\text { well }\end{array}$ & $\begin{array}{l}\text { What } \\
\text { went } \\
\text { wrong? }\end{array}$ & $\begin{array}{l}\text { What should we do } \\
\text { better? }\end{array}$ \\
\hline $\begin{array}{l}\text { Semua tugas } \\
\text { selesai tepat } \\
\text { waktu }\end{array}$ & - & - \\
\hline
\end{tabular}

5. Sprint Kedua

Sprint planning kedua berencana untuk menyelesaikan product backlog Authentication dan user management admin. Berikut hasil review dari sprint kedua:

a. Halaman Login

Merupakan halaman untuk pengguna melakukan login.

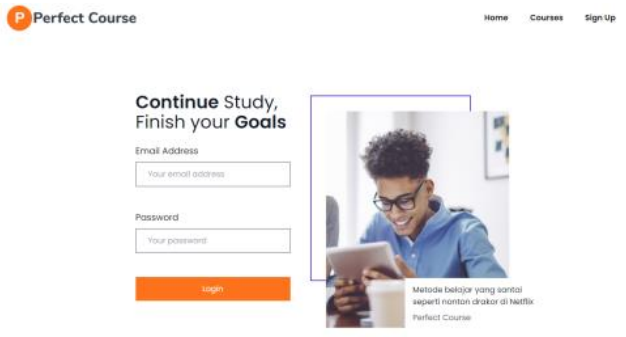

Gambar 4. Halaman Login

b. Halaman Register

Merupakan halaman untuk pengguna melakukan register akun.

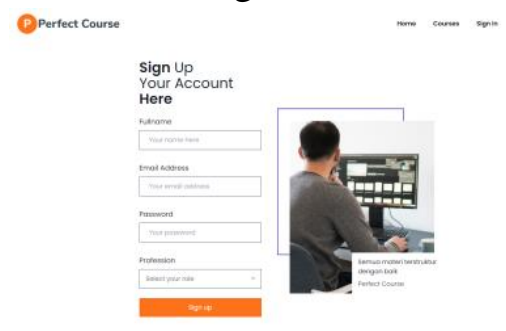

Gambar 5. Halaman Register

c. Halaman User Management

Merupakan halaman untuk admin melihat jumlah pengguna yang terdaftar disistem, mendaftarkan pengguna baru dan mengubah profile pengguna.

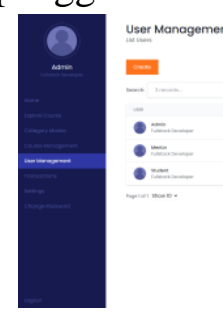

Gambar 6. Halaman List User

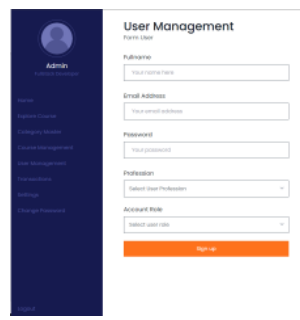

Gambar 7. Halaman Form Add User 


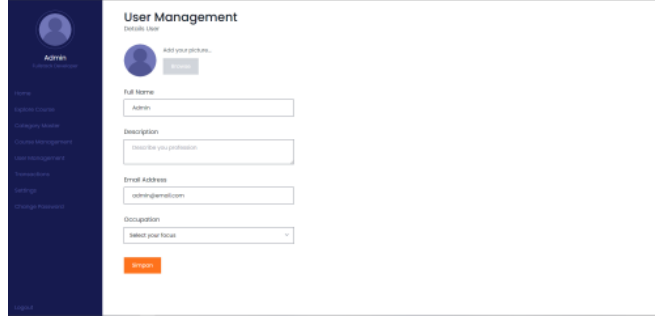

Gambar 8. Halaman Form Edit User

d. Pengujian Blackbox

Berikut adalah hasil pengujian blackbox pada hasil sprint review 2 .

Tabel 6. Hasil Pengujian Blackbox Sprint 2

\begin{tabular}{lll}
\hline Testing & Expected Result & $\begin{array}{l}\text { Resul } \\
\mathbf{t}\end{array}$ \\
\hline User Login & $\begin{array}{l}\text { Pengguna dapat } \\
\text { mengakses OK } \\
\text { halaman login } \\
\text { dan melakukan }\end{array}$ & \\
& login & \\
\hline Register & $\begin{array}{l}\text { Pengguna dapat } \\
\text { mengakses OK }\end{array}$ & \\
& halaman register \\
& dan melakukan & \\
& register akun & \\
\hline Logout & $\begin{array}{l}\text { Pengguna dapat } \\
\text { keluar dari sistem }\end{array}$ \\
& setelah login \\
\hline User & $\begin{array}{l}\text { Admin dapat } \\
\text { mendaftarkan, }\end{array}$ \\
Management & \\
& dan mengedit & \\
profile pengguna & \\
\hline
\end{tabular}

Setelah sprint review 2 selesai, terdapat sprint retrospective dari sprint kedua:

Tabel 7. sprint retrospective 2

\begin{tabular}{lll}
\hline $\begin{array}{l}\text { What went } \\
\text { well }\end{array}$ & $\begin{array}{l}\text { What went } \\
\text { wrong? }\end{array}$ & $\begin{array}{l}\text { What should } \\
\text { we do better? }\end{array}$ \\
\hline Semua tugas & $\begin{array}{l}\text { kode } \\
\text { perancangan }\end{array}$ & $\begin{array}{l}\text { Melakukan } \\
\text { perapian kode }\end{array}$ \\
waktu tepat & $\begin{array}{l}\text { sistem tidak } \\
\text { pada sistem } \\
\text { rapi }\end{array}$ & $\begin{array}{l}\text { yang telah } \\
\text { dirancang }\end{array}$ \\
& &
\end{tabular}

6. Sprint Ketiga

Sprint planning ketiga berencana untuk menyelesaikan product backlog course management, berupa perancangan fitur publikasi kursus disistem. Berikut hasil review dari sprint ketiga: a. Halaman Course Management Merupakan halaman untuk melakukan publikasi, mengedit dan menghapus kursus.

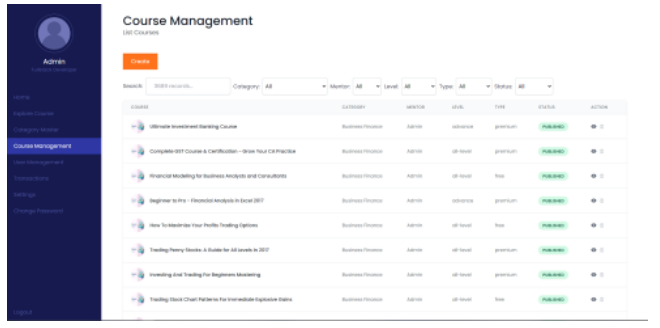

Gambar 9. Halaman List Course

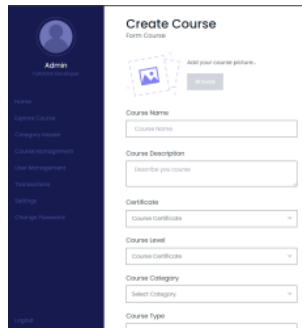

Gambar 10. Halaman Create Course

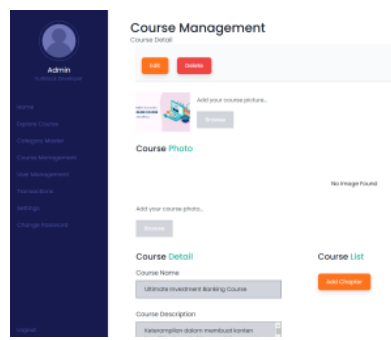

Gambar 11. Halaman Detail \& Edit Course

b. Pengujian Blackbox

Berikut adalah hasil pengujian blackbox pada hasil sprint review 3.

Tabel 8. Hasil Pengujian Blackbox Sprint 3

\begin{tabular}{lll}
\hline Testing & $\begin{array}{l}\text { Expected } \\
\text { Result }\end{array}$ & Result \\
\hline Course & Pengguna & OK \\
Management & dapat & \\
& melakukan & \\
& mempublikasi, & \\
& melihat, & \\
& mengubah, dan & \\
& menghapus & \\
& kursus & \\
\hline
\end{tabular}

Setelah sprint review 3 selesai, terdapat sprint retrospective dari sprint ketiga: 
Tabel 9. sprint retrospective 3

\begin{tabular}{|c|c|c|}
\hline $\begin{array}{l}\text { What went } \\
\text { well }\end{array}$ & $\begin{array}{l}\text { What went } \\
\text { wrong? }\end{array}$ & $\begin{array}{l}\text { What should } \\
\text { we do better? }\end{array}$ \\
\hline $\begin{array}{l}\text { Semua tugas } \\
\text { selesai tepat } \\
\text { waktu }\end{array}$ & $\begin{array}{l}\text { Tabel list } \\
\text { kursus tidak } \\
\text { menerapkan } \\
\text { pagination }\end{array}$ & $\begin{array}{l}\text { Menerapkan } \\
\text { pagination } \\
\text { untuk } \\
\text { menampilkan } \\
\text { list data }\end{array}$ \\
\hline
\end{tabular}

\section{Sprint Keempat}

Sprint planning keempat berencana untuk menyelesaikan product backlog course enrollment dan payment method, berupa perancangan fitur pembelian kursus dan metode pembayaran. Berikut hasil review dari sprint keempat:

a. Halaman Home

Merupakan halaman yang menampilkan list kursus yang terlah dipublikasi oleh admin dan mentor.

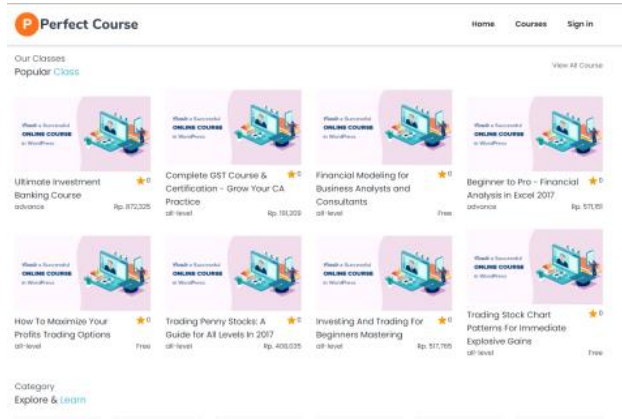

Gambar 12. Halaman Home

b. Halaman Detail Course

Merupakan halaman yang menampilkan detail list kursus yang telah dipublikasi.

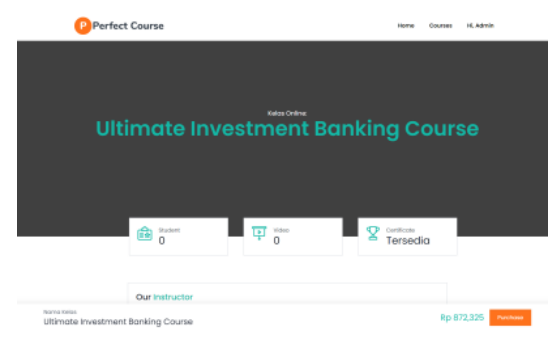

Gambar 13. Halaman Detail Course

c. Halaman Pembayaran Midtrans
Merupakan halaman untuk melakukan pembayaran pembelian kursus.

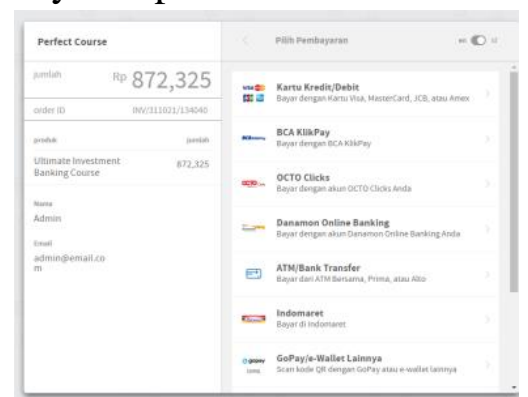

Gambar 14. Halaman Pembayaran

\section{d. Halaman Lihat Kursus}

Merupakan halaman untuk menonton kursus yang telah dibeli oleh pengguna.

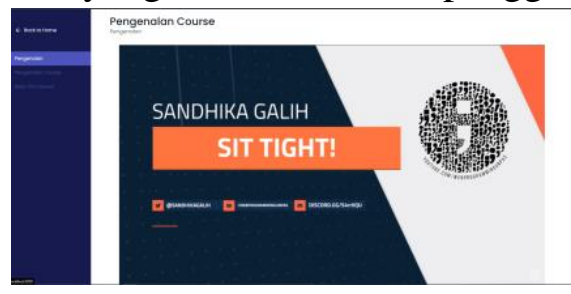

Gambar 15 Halaman Lihat Kursus

e. Pengujian Blackbox

Berikut adalah hasil pengujian blackbox pada hasil sprint review 4 .

Tabel 10. Hasil Pengujian Blackbox Sprint 4

\begin{tabular}{llll}
\hline Testing & \multicolumn{2}{l}{ Expected Result } & Result \\
\hline View Detail & $\begin{array}{l}\text { Pengguna dapat } \\
\text { melihat detail }\end{array}$ & \\
& kursus & \\
\hline Payment & $\begin{array}{l}\text { Pengguna dapat } \\
\text { melakukan }\end{array}$ & \\
Midtrans & $\begin{array}{l}\text { OK } \\
\text { pembayaran via }\end{array}$ \\
& midtrans untuk \\
& kursus berbayar & \\
Enroll & Pengguna dapat & OK \\
Course & $\begin{array}{l}\text { enroll course } \\
\text { gratis dan enroll }\end{array}$ \\
& course berbayar \\
\hline Watch & $\begin{array}{l}\text { Pengguna dapat } \\
\text { melihat kursus }\end{array}$ \\
Course & yang telah di \\
& enroll \\
\hline
\end{tabular}

Setelah sprint review 4 selesai, terdapat sprint retrospective dari sprint ketiga: 
Tabel 11. sprint retrospective 3

\begin{tabular}{lll}
\hline $\begin{array}{l}\text { What went } \\
\text { well }\end{array}$ & $\begin{array}{l}\text { What went } \\
\text { wrong? }\end{array}$ & $\begin{array}{l}\text { What should } \\
\text { we do better? }\end{array}$ \\
\hline $\begin{array}{l}\text { Semua tugas } \\
\text { selesai tepat }\end{array}$ & - & - \\
waktu & & \\
\hline
\end{tabular}

\section{Sprint Kelima}

Sprint planning kelima berencana untuk menyelesaikan product backlog yang tersisa, yaitu system recommender course dan microservices, berupa perancangan fitur rekomendasi kursus dan integrasi antar service API yang telah dirancang. Berikut hasil review dari sprint kelima:

a. Hasil Desain Sistem Rekomendasi Bagian ini membahas tentang alur kerja sistem rekomendasi yang telah dirancang, ditampilkan pada gambar 16.

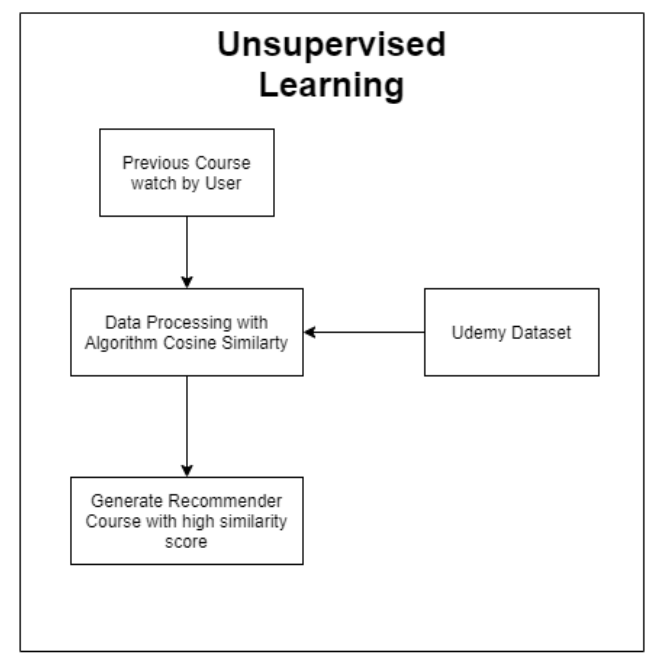

Gambar 16. Alur Sistem Rekomendasi

Sumber: [29]

Pada tahap pertama, sistem akan mengambil kursus terakhir yang pernah diakses oleh user, bersama data semua kursus dari udemy dataset. Selanjutnya sistem akan melakukan proses penghapusan stopwords dan count vectorization pada seluruh data atribut course title. Hasil penghapusan stopwords ditunjukan pada tabel 11.

Tabel 12. Penghapusan Stopwords

\begin{tabular}{|c|c|}
\hline Course Title & Clean Course Title \\
\hline $\begin{array}{l}\text { Ultimate Investment } \\
\text { Banking Course }\end{array}$ & $\begin{array}{l}\text { Ultimate Investment } \\
\text { Banking Course }\end{array}$ \\
\hline $\begin{array}{lr}\text { Complete } & \text { GST } \\
\text { Course } & \& \\
\text { Certification } & \text { - Grow } \\
\text { You... }\end{array}$ & $\begin{array}{l}\text { Complete GST } \\
\text { Course Certification } \\
\text { Grow Practice }\end{array}$ \\
\hline $\begin{array}{l}\text { Financial Modeling } \\
\text { for Business } \\
\text { Analysts and C... }\end{array}$ & $\begin{array}{lr}\text { Financial Modeling } \\
\text { Business Analysts } \\
\text { Consultants }\end{array}$ \\
\hline $\begin{array}{l}\text { Beginner to Pro - } \\
\text { Financial Analysis } \\
\text { in Excel ... }\end{array}$ & $\begin{array}{lr}\text { Beginner } & \text { Pro } \\
\text { Financial } & \text { Analysis } \\
\text { Excel 2017 } & \end{array}$ \\
\hline $\begin{array}{l}\text { How To Maximize } \\
\text { Your Profits } \\
\text { Trading Options }\end{array}$ & $\begin{array}{l}\text { Maximize Profi } \\
\text { Trading Options }\end{array}$ \\
\hline
\end{tabular}

Setelah melakukan penghapusan stopwords, selanjutnya melakukan perhitungan count vectorizer $(\mathrm{CV})$ dari seluruh data atribut course title. Hasil dari sparse matrix $\mathrm{CV}$ dan nama kursus yang terakhir diakses oleh pengguna akan diolah oleh algoritma cosine similarity untuk menentukan hasil rekomendasi kursus yang memiliki nilai kesamaan tertinggi.

Tabel 13. Evaluasi Hasil Rekomendasi

\begin{tabular}{|c|c|c|}
\hline $\begin{array}{l}\text { Profile } \\
\text { User }\end{array}$ & $\begin{array}{l}\text { Recommender } \\
\text { Course }\end{array}$ & $\begin{array}{l}\text { Similarity } \\
\text { Score }\end{array}$ \\
\hline \multirow{10}{*}{$\begin{array}{l}\text { Trading } \\
\text { Options } \\
\text { Basics }\end{array}$} & $\begin{array}{l}\text { Options Trading 101: } \\
\text { The Basics }\end{array}$ & 0.87 \\
\hline & $\begin{array}{l}\text { Trading Options For } \\
\text { Consistent Returns: } \\
\text { Option... }\end{array}$ & 0.82 \\
\hline & Basics of Trading & 0.82 \\
\hline & $\begin{array}{lr}\text { Options } & \text { Trading } \\
\text { Basics } & \text { (3-Course } \\
\text { Bundle) } & \\
\end{array}$ & 0.77 \\
\hline & $\begin{array}{ll}\text { Trading: Basics } & \text { of } \\
\text { Trading } & \text { for } \\
\text { Beginners } & \end{array}$ & 0.71 \\
\hline & $\begin{array}{l}\text { Options Basics \& } \\
\text { Trading with Small } \\
\text { Capital! }-\ldots\end{array}$ & 0.71 \\
\hline & $\begin{array}{l}\text { Options Trading - } \\
\text { How to Win with } \\
\text { Weekly Options }\end{array}$ & 0.65 \\
\hline & $\begin{array}{l}\text { Intermediate Options } \\
\text { trading concepts for } \\
\text { Stoc... }\end{array}$ & 0.61 \\
\hline & $\begin{array}{l}\text { Forex Trading with } \\
\text { Fixed 'Risk through } \\
\text { Options... }\end{array}$ & 0.61 \\
\hline & The Advantages of & \\
\hline
\end{tabular}




\begin{tabular}{|c|c|}
\hline $\begin{array}{l}\text { ETF Options and } \\
\text { Index Option... }\end{array}$ & 0.61 \\
\hline $\begin{array}{l}\text { Options } \\
\text { Bundle- the heart of } \\
\text { Options ... }\end{array}$ & 0.61 \\
\hline $\begin{array}{l}\text { How To Maximize } \\
\text { Your Profits Trading } \\
\text { Options }\end{array}$ & 0.58 \\
\hline
\end{tabular}

Tabel 13 menunjukan 13 rekomendasi kursus yang serupa dengan "Trading Options Basics" berdasarkan nilai kesamaan tertinggi dari algoritma cosine similarity.

b. Hasil Integrasi Microservices

Tahapan integrasi microservices menggunakan API Gateway sebagai perantara interaksi service course dan service rekomendasi kursus, ditunjukan pada gambar 17.

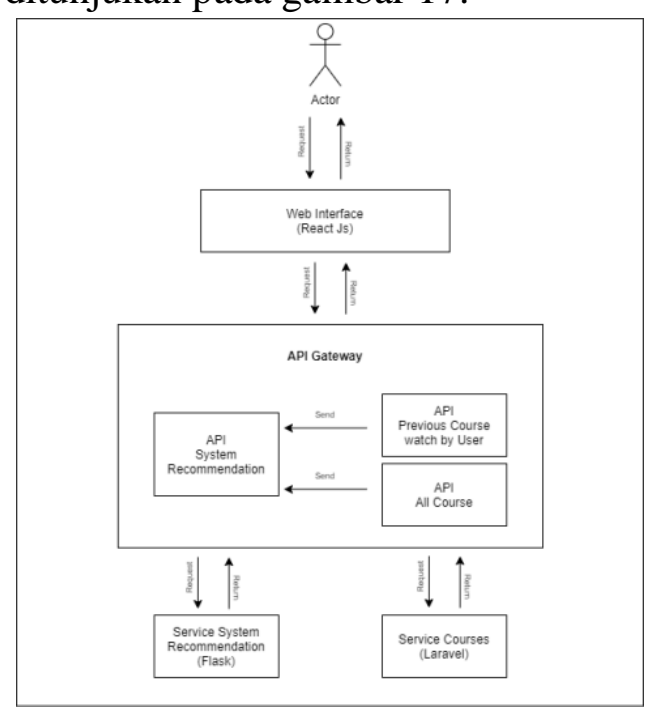

Gambar 17 Alur Kerja Microservices

Rekomendasi Kursus

API Gateway akan mengambil parameter riwayat kursus yang pernah diakses oleh pengguna dan semua kursus dari service course kirim ke API Gateway. Kemudian API Gateway akan meneruskannya ke service rekomendasi kursus. Service rekomendasi kursus akan mengembalikan hasil rekomendasi ke API Gateway dan API Gateway meneruskan kepada tampilan web pengguna. Berikut hasil perancangan rekomendasi kursus pada sistem.

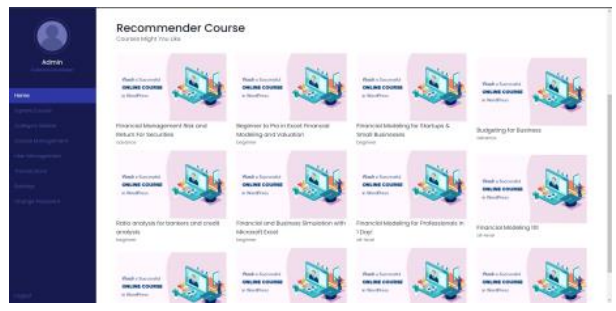

Gambar 18 Halaman List Rekomendasi Kursus

\section{c. Hasil Pengujian Blackbox}

Berikut adalah hasil pengujian blackbox pada hasil sprint review 5 .

Tabel 14. Hasil Pengujian Blackbox Sprint 5

\begin{tabular}{lll}
\hline Testing & $\begin{array}{l}\text { Expected } \\
\text { Result }\end{array}$ & Result \\
\hline View & Pengguna & OK \\
Recommender & $\begin{array}{l}\text { dapat melihat } \\
\text { Course }\end{array}$ & \\
& rekomendasi & \\
& kursus & \\
\hline
\end{tabular}

\section{KESIMPULAN}

Terdapat beberapa kesimpulan yang bisa diambil dari hasil penelitian tersebut, yaitu:

1. Aplikasi kursus online tersebut dirancang dengan metode scrum, dengan tujuan untuk mengidentifikasi masalah dengan cepat dalam proses pengembangan proyek.

2. Aplikasi kursus online tersebut sudah terintegrasi dengan sistem rekomendasi unsupervised learning dengan metode content-based filtering. Sistem rekomendasi tersebut dapat menawarkan kursus yang memiliki nilai kesamaan yang tinggi dengan riwayat akses pengguna.

3. Dengan adanya aplikasi tersebut, diharapkan dapat membantu pengguna, terutama pelajar yang ada di Kota Batam dalam mencari kursus online untuk melakukan pengembangan keterampilan. 


\section{DAFTAR PUSTAKA}

[1] A. S. Syarifudin, "Impelementasi Pembelajaran Daring Untuk Meningkatkan Mutu Pendidikan Sebagai Dampak Diterapkannya Social Distancing," J. Pendidik. Bhs. dan Sastra Indones. Met., vol. 5, no. 1, pp. 31-34, 2020, doi: 10.21107/metalingua.v5i1.7072.

[2] A. D. Ismail, A. F. Jamil, and A. Adityo, "Manajemen Humas Smk Muhammadiyah 9 Wagir Untuk Meningkatkan Kredibilitas Sekolah," SELAPARANG J. Pengabdi. Masy. Berkemajuan, vol. 2, no. 1, p. 13, 2018, doi: 10.31764/jpmb.v2i1.557.

[3] Mulyadi, Hoiriah, D. Supriadi, and R. Mugiati, "Sistem Informasi Pendaftaran Kursus Berbasis Web Pada Yayasan Musik Jakarta," IJCIT (Indonesian J. Comput. Inf. Technol., vol. 3, no. 2, pp. 2-3, 2018.

[4] W. N. Zaniar Siswantin, "Pendidikan luar sekolah fakultas ilmu pendidikan universitas negeri semarang 2017," 2017.

[5] W. Tan, "Pemenuhan Hak Pendidikan Anak Jalanan di Kota Batam: Tantangan Dalam Mewujudkan Sustainable Development Goals (SDGs)," Supremasi Huk. J. Penelit. Huk., vol. 29, no. 1, pp. 46-59, 2020, doi: $\quad$ 10.30641/ham.2019.10.179194.1.

[6] BPS Batam, "Keadaan Ketenagakerjaan Kota Batam 2020," Badan Pus. Stat., no. 86, p. 2, 2020.

[7] Badan Pusat Statistik, "Buletin Resmi Statistik Keadaan Ketenagakerjaan Indonesia Februari 2021," vol. 19, no. 37, pp. 1-28, 2021.

[8] S. Indayani and B. Hartono, "Analisis Pengangguran dan Pertumbuhan Ekonomi sebagai Akibat Pandemi Covid-19," J. Perspekt., vol. 18, no. 2, pp. 201-208, 2020.

[9] N. W. Erwin Rifal Fauzi, "PERAN LEMBAGA KURSUS DAN PELATIHAN MENJAHIT DALAM
MEMPERKUAT MANAJEMEN PEMBERDAYAAN

MASYARAKAT DI DESA

PADALARANG," J. Comm-Edu, vol. 1, no. 3, pp. 14-19, 2018.

[10] R. Morsomme and S. V. Alferez, "Content-based course recommender system for liberal arts education," EDM 2019 - Proc. 12th Int. Conf. Educ. Data Min., no. Edm, pp. 748753, 2019.

[11] C. Focil-Arias, J. Ziiniga, G. Sidorov, I. Batyrshin, and A. Gelbukh, "A Tweets Classifier Based on Cosine Similarity," CEUR Workshop Proc., vol. 1866, 2017.

[12] Raghav Mehta and Shikha Gupta, "Movie Recommendation Systems using Sentiment Analysis and Cosine Similarity," Int. J. Mod. Trends Sci. Technol., vol. 7, no. 01, pp. 16-22, 2021, doi: 10.46501/ijmtst0701004.

[13] H. Sucipto et al., "Rancang Bangun ELearning Lembaga Kursus dan Keterampilan ( LKP ) Studi Kasus LKP Istikom," pp. 1-7, 2021.

[14] M. B. Taftayani et al., "Jurnal Tugas Akhir Universitas Telkom Website Menggunakan Framework Laravel Dan Framework Css Materialize Pada," vol. 6, no. 2, pp. 8124-8130, 2019.

[15] A. K. Bienderil Komalaa, "Model Reservasi Massage Berbasis Website Menggunakan Algoritma FIFO dengan Metode Scrum," vol. 2, no. 3, pp. 1-8, 2018.

[16] "Metodologi Scrum." https://socs.binus.ac.id/2019/12/23/m etodologi-scrum/ (accessed Oct. 25, 2020).

[17] S. Al-Saqqa, S. Sawalha, and H. Abdelnabi, "Agile Software Development: Methodologies and Trends," Int. J. Interact. Mob. Technol., vol. 14, no. 11, pp. 246-270, 2020.

[18] Scrum.org, "The Scrum Framework Poster | Scrum.org." https://www.scrum.org/resources/scru 
m-framework-poster (accessed Sep. 18, 2021).

[19] L. Gonçalves, "Scrum," Control. Manag. Rev., vol. 62, no. 4, pp. 40-42, May 2018, doi: 10.1007/s12176-0180020-3.

[20] F. Kussunga and P. Ribeiro, "ScienceDirect ScienceDirect Proposal of a Visual Environment to Support Scrum Proposal of a Visual Environment to Support Scrum," Procedia Comput. Sci., vol. 164, pp. 491-497, 2019, doi: 10.1016/j.procs.2019.12.211.

[21] "What is an Increment in Scrum?" https://www.scrum.org/resources/wha t-is-an-increment (accessed Oct. 29, 2020).

[22] M. Ngolu Hotdiana Simanullang, Auliya Wardah Bilah Siregar, "Sistem Informasi Pemesanan Menu Makanan Pada Rm Sedep Roso Rantauprapat Berbasis Web," J. Student Dev. Informatics Manag., vol. 1, pp. 12-18, 2021.

[23] M. Von Emster, M. H. Abdullah, and J. Sabtu, "Sistem Informasi Pengaduan Kekerasan Perempuan dan Anak pada DP3A Kota Ternate Berbasis Website dengan Menggunakan PHP dan Mysql," $J$. JAMINFOKOM, vol. 1 , no. 1, pp. 4654, 2021.

[24] F. Ramadhan and A. Musdholifah, "Online Learning Video Recommendation System Based on Course and Sylabus Using ContentBased Filtering," no. x, pp. 1-10, 2021, doi: 10.22146/ijccs.Xxxx.

[25] K. S. Y. Ahmad Turmudi, "Analisa Sentimen Tweet Indonesia Menggunakan Fitur Ekstrasi Dan Teknik Cross Validation Terhadap Model Naïve Bayes," Anal. Sentimen Tweet Indones. Menggunakan Fitur Ekstrasi Dan Tek. Cross Valid. Terhadap Model Nä̈ve Bayes, vol. 54, no. 4, pp. 337-348, 2020, doi: 10.31857/s0320930x20040088.

[26] A. A. Neamah and A. S. El-Ameer,
"Design and Evaluation of a Course Recommender System Using ContentBased Approach," ICOASE 2018 - Int. Conf. Adv. Sci. Eng., pp. 1-6, 2018, doi: 10.1109/ICOASE.2018.8548789.

[27] L. Suryani and K. Edy, "Pengembangan Aplikasi 'Lost \& Found' Berbasis Android Dengan Menggunakan Metode Term Frequency - Inverse Document Frequency (Tf-Idf) Dan Cosine Similarity," Electro Luceat, vol. 6, no. 2, pp. 190-204, 2020, doi: 10.32531/jelekn.v6i2.232.

[28] R. A. Putra, "Analisa Implementasi Arsitektur Microservoces Berbasis Kontainer Pada Komunitas Pengembang Perangkat Lunak Sumber Terbuka ( OpenDayLight DevOps Community )," J. Sist. Infomasi Teknol. Inf. dan Komput. (Just It) Univ. Bina Nusant. Magister Manaj. Sist. Inf. Jakarta, pp. 150-162, 2018.

[29] N. Buslim and R. P. Iswara, "Pengembangan Algoritma Unsupervised Learning Technique Pada Big Data Analysis di Media Sosial sebagai media promosi Online Bagi Masyarakat," J. Tek. Inform., vol. 12, no. 1, pp. 79-96, 2019, doi: 10.15408/jti.v12i1.11342. 